\title{
Carbon Footprint Calculation and Proposing Green Growth Solutions Towards A Low Carbon Economy for Garment Technology Processes in Vietnam
}

NGUYEN LE ${ }^{1}$ and Le Nguyen ${ }^{2}$

${ }^{1}$ Affiliation not available

${ }^{2} \mathrm{PhD}$ Sudent, Department of Water resources and Environmental engineering, TamKang University

January 20, 2022

\section{Hosted file}

Carbon Footprint_Vietnam_LeNguyen.pdf available at https://authorea.com/users/450157/ articles/553037-carbon-footprint-calculation-and-proposing-green-growth-solutions-

towards-a-low-carbon-economy-for-garment-technology-processes-in-vietnam 